\title{
CONCEPTUAL MODEL FOR INSTITUTIONAL ANALYSIS OF THE SOCIAL SERVICES PLANNING PRACTICE
}

\author{
Margarita Bogdanova ${ }^{1}$, Penka Shishmanova ${ }^{2}$, Evelina Parashkevova ${ }^{3}$, Mariela \\ Stoyanova ${ }^{4}$
}

${ }^{1}$ Prof. Dr., "D. A. Tsenov" Academy of Economics, BULGARIA, m.bogdanova@uni-svishtov.bg

${ }^{2}$ Prof. Dr., "D. A. Tsenov" Academy of Economics, BULGARIA, p.shishmanova@uni-svishtov.bg

${ }^{3}$ Assoc.Prof. Dr., "D. A. Tsenov" Academy of Economics, BULGARIA, e.parashkevova@unisvishtov.bg

${ }^{4}$ Assist.Prof. Dr., "D. A. Tsenov" Academy of Economics, BULGARIA, m.stoyanova@unisvishtov.bg

\begin{abstract}
The planning of social services in Bulgaria is carried out in a complex normative and institutional environment, which is constantly changing. Reform of the process of planning social services in the direction of their decentralization is underway, but for many reasons the reform is slowing down. This complicates the process of identifying social problems and finding solutions to overcome them, especially at regional and local level.

The institutional analysis of the social services system clarifies the main (formal and informal) participants in the process of planning and implementation of social services and their motives and possibilities for coordination. The analysis makes it possible to understand how the social services sector functions, what incentives it creates and how individual institutions influence people's behavior and, consequently, the wealth of society.

The aim of the paper is to clarify the planning environment of social services in Bulgaria and to outline the institutional framework of planning and the internal interrelationships. The study is based on the methodological individualism approach, which seeks explanations in social knowledge based on individuals and their properties, motives, goals and beliefs. The object of analysis are the desires (plans) of the economic agents, which at a certain moment are coordinated and thus transactions are carried out. Some incentives have been clarified, which motivate them to act in a certain way under conditions of limited access to resources (material, human and financial). Special emphasis is placed on transaction costs, which slow down the operation of the system and make it difficult to achieve its goals.

Aspects of cooperation in the development of a map of social services and in the coordination of social service providers are discussed. Informal relations, such as customs, culture and attitudes of local communities, remain outside the model. The institutional analysis approach can be used in both research and training of public sector employees in clarifying the objectives, principles and scope of various aspects of the social services system.
\end{abstract}

Keywords: Institutional analysis, Social services planning, Casual loop diagram, Coordination

\section{INTRODUCTION}

Social policy is one of the key and most discussed public policies, both in Bulgaria and in other countries, especially in a period of dealing with the consequences of the Covid-19 pandemic, in which the world is at the moment. This requires activity and proactivity of the institutions and actions in response to actually identified problems, adequate formulation, decision-making and their implementation. Social problems 
cannot be postponed, and the process of strategic planning is long and should involve all participants. That is why the good coordination and integration of the institutions engaged in the provision of social services and support at national and regional level is extremely important. However, in the current practice in Bulgaria there are a number of weaknesses in this regard, most of which are inherited and permanently implanted in the actions or inactions of various bodies and structures.

The aim of the paper is to present the environment of social services planning and to outline conceptually the institutional framework of planning and the interrelations between the institutions in it. Special emphasis is placed on the need for coordination in those parts of the system where there is the greatest deficit of interconnectedness of actions.

\section{THE INSTITUTIONAL APPROACH AS A MEANS OF ANALYSIS IN THE PLANNING OF SOCIAL SERVICES}

Social services are defined as a form of support for certain groups in society, which creates opportunities for individuals to lead an independent lifestyle and be able to carry out their daily activities, as well as to overcome their possible social isolation. At the heart of these desired effects are the correct identification of the needs for social services, their timely provision and quality implementation. An important condition for achieving them is good planning, which is a guarantee that people in need will receive the necessary care and support. At the same time, adequate planning and development of social services will contribute to stimulating the initiative and flexibility of administrations at regional and local level and will prevent the irrational spending of valuable financial, material and human resources of society. All this requires a reliable analysis of the practices for planning social services with attention to many factors, having different sources and influencing at different levels.

The specifics of the social services sector and the need for a qualitative analysis of their planning and implementation at regional and local level require an assessment of the role of the institutional factor to modify and enrich the orthodox theoretical economic model. The application of the institutional approach to the analysis allows to highlight the main participants (formal and informal) in the planning and implementation of social services, to clarify their roles and responsibilities, to consider the interactions between them and the impact of institutions on individuals, groups and society as a hole.

The specifics of the social services sector and the need for a qualitative analysis of their planning and implementation at regional and local level require an assessment of the role of the institutional factor to modify and enrich the orthodox theoretical economic model. The application of the institutional approach to the analysis allows to highlight the main participants (formal and informal) in the planning and implementation of social services, to clarify their roles and responsibilities, to consider the interactions between them and the impact of institutions on individuals, groups and society generally.

In theoretical terms, institutional analysis focuses on the norms, rules and constraints within which the processes take place and examines the behavior of individuals and groups. It is based on the understanding that the functioning of the economy and its main segments is determined not only by its natural internal forces, but is closely related and dependent on external factors, such as institutions in society. They coordinate and stimulate the behavior of economic agents and structure the interaction between them.

In this sense, the institutional analysis of the planning of social services reveals how the institutes contribute to the protection of fundamental human rights and support the social integration of people at risk, i.e. how they guide the behavior of individuals from vulnerable groups and how they motivate them to make the right choices. In general, the analysis forms an idea of the functioning of the social services sector, its determinants, the strengths and deficits in the system and based on the results provides additional opportunities for improving social policy.

Historically, the institutional analysis is connected with the historical-sociological (institutional) direction in economic thought that emerged in the 19th century, which is opposed to the abstract-logical (liberalclassical) direction. The conflict between them remains relevant - classicism focus on pure economic theory, offering formalized analytical models of the functioning of the economy without institutions, in contrast to which institutionalism derives the key role of institutions not only for the functioning of the economy but also for social change in general. (Кънев, 2005, с.17).

Unlike the classical and neoclassical approach, based on the naturally established order, spontaneity of action, predictability and relative constancy of preferences, statics, deductivism, etc., the institutional approach expands the research field to include such factors as traditions, customs, norms, rules (ie institutes), which makes the analysis more comprehensive and realistic. This in turn contributes to the 
greater objectivity of economic research, and the follow-up actions (setting goals, priorities, measures) become more adequate to the needs. These differences between the two approaches largely determine the main characteristics of institutional analysis:

- It examines economic problems and their possible solutions not in isolation and limited only within the economic context, but in direct dependence on many non-economic factors (political, legal, social, psychological, ethical, cultural, etc.). This takes into account the influence of the external environment of organizations, which is objective in nature, and economic agents are "forced" to adapt to it by forming specific behavior.

- It expands the understanding of economics and defines it as a dynamic system. The action of market forces shows not only the pursuit of equilibrium (static state), but also evolution. The understanding is that equilibrium or the pursuit of it cannot explain the reasons for changes in the economy. It should be seen as a process in development. Moreover, evolutionary change is not seen as spontaneous, but as a purposeful, controlled process.

- Gives priority to the inductive method of research, and the aim is to draw summaries and conclusions on the basis of specific facts, i.e. the research should be based on real reality and not be burdened with assumptions that would compromise its value. It imposes the principle of empiricism to avoid absolute, "conservative" faith in the market and laissez-faire" (Винокуров, 2014, с. 10).

- Emphasizes the application of an economic approach to social structures and relations (i.e. takes into account the impact of institutions on access to and processing of information, property rights, public choice, negotiation, etc.). In this regard, the analysis also takes into account the objectively incurred transaction costs 1 , thus contributing to the determination of the true cost of an activity.

- It examines the problem of economic uncertainty in market conditions and on the basis of the asymmetry of information and subjective expectations for the future explains the incomplete rationality of economic entities. The institutes in this case are presented as a mechanism for adapting people's behavior to the environment of uncertainty and minimizing costs and losses.

Naturally, the institutional analysis also has negative aspects, which derive from its nature and are valid for all analyzed systems and processes, in particular for the planning of social services. Imperfections are generally related to the imposition of frameworks and certain limitations in terms of individual judgment and vision for the organization of the planning process; insufficient flexibility of some institutes (especially informal ones); multifactorial analysis, divergent action of factors and difficult to determine the final effect; lack and asymmetry of information; subjectivism in the interpretation of the initial data and the possibility of wrong decisions, possible interference of political interests in the social sphere, etc.

\section{ANALYSIS OF THE INSTITUTIONS FOR SOCIAL SERVICES AT NATIONAL AND REGIONAL LEVEL IN THE REPUBLIC OF BULGARIA}

The institutions in the system of social services are regulated by the legal framework of the country, which includes several basic laws. The most relevant is the Social Services Act (SSA), adopted in 2020 after lengthy discussions with stakeholders and implementation of a detailed Roadmap of the members of the Working Group and the Ministry of Labor and Social Policy. Such an initiative, with specifically regulated public consultations, wide search for feedback and discussions, is a common practice in the development of other normative documents, but in practice the process of involving civil society is rather formal. SSA in an innovative way makes a request to change the legal framework for planning, provision, financing and control of social services, which during the current programming period operates slowly, uncoordinated and in a complex institutional environment. The social policy framework outlined in the new law relies on deinstitutionalisation, a new concept of access and new quality and control standards, which aim to reduce the asymmetries identified so far with regard to the provision of social services tailored to the real needs of the target groups and an adequately functioning institutional apparatus.

The SSA clearly specifies national and local authorities and social service providers and their functions. However, how they perform them, what responsibilities are imposed, whether the internal and external communication channels function, how monitoring and control is carried out, as well as other issues determining the quality of the offered services are subject to more in-depth study and research of multiple interconnections.

\footnotetext{
${ }^{1}$ Transaction costs added to production costs form the total transaction costs.
} 


\subsection{Central Level Bodies}

The Social Services Act (SSA) regulates the functions regarding the implementation of social policy of the following institutions at the central level: Council of Ministers, Ministry of Labor and Social Policy, Agency for Social Assistance, Agency for quality of social services, Cooperation at national level.

In current practice, social policy at the national level is implemented by the Ministry of Labor and Social Policy, which reports to the Council of Ministers through the Agency for Social Assistance, which supports district administrations in the process of developing strategies for social services at the district level. They, in turn, are reflected in the municipal strategies for the development of social services and the annual plans for the development of social services. Regarding the planning of strategic documents at different levels, many traditional weaknesses stand out, some of which are: inadequately defined goals, incorrect definition of vision, priorities, indicators, unclear communication links and responsibilities. This is an indicator of both the lack of expert planning capacity in the institutions responsible for shaping social policy and the lack of good inter-institutional relations and control.

The new moment is the establishment of the Agency for Quality of Social Services, which comes as an attempt to overcome significant problems in terms of the quality of services offered and social support so far. The body will be an executive agency under the Minister of Labor and Social Policy and will control the observance of the standards for quality of social services and the requirements of the SSA, the observance of the rights of the consumers and the spending of funds from the state budget.

On the one hand, it can be assumed that the creation of another institutional level is too large an expansion of the administration, which is a permanent shortcoming of the public system as a whole, but on the other hand the adequate functioning of such an agency is urgent. It is precisely the weaknesses in the quality of the offered social services, their efficiency and effectiveness that are challenges that the system in Bulgaria still cannot cope with.

The data as a result of analyzes of the satisfaction of the vulnerable groups with the offered social services are of exceptional importance for the updating in the dynamics of the social policy. For this reason, the ongoing monitoring at national level, charged as a function of the Agency for Quality of Social Services, is an important prerequisite for improving quality.

Regarding the cooperation at the national level, SSA lays down a regulation for joint and coordinated actions of all mentioned bodies, both at national, regional and local level and between all social partners, social service providers, non-profit legal entities for public benefit activities, higher education institutions, professional organizations of specialists providing social services, international organizations and persons using social services. This wide range of persons and bodies involved in the social process additionally requires a strictly regulated and clear communication system, which allows for integrated and complementary actions on the part of the institutional apparatus. Here, one of the most controversial points is the way in which non-governmental organizations are involved. The main shortcoming of the current practice is the lack of a specific process of stakeholder involvement and the way in which their selection is carried out. There is a formal implementation of this requirement, which, however, deprives the process of creating and implementing social policy by actual key players.

\subsection{Bodies At Regional And Local Level}

The Social Services Act regulates the functions regarding the implementation of the social policy of the following institutions at regional and local level: District governors, Local self-government bodies, Cooperation at the municipal level, Social Services Council.

The direct social policy is implemented precisely by the bodies at regional and local level. They are the ones who are in close contact with vulnerable groups and need to recognize their needs. The main planning documents in which their direct commitments and hierarchical-communication relations are described are the Regional strategies for development of social services, the Municipal strategies for development of social services and the Annual plans for development of social services. In the general case, they provide for partnership between the various structures in a broad sense, including between municipalities and sectors, building networks at regional and local level in order to combine available and potential resources, complementing and coordinating the activities of the institutions involved from different sectors, with a focus on service users, vulnerable communities and other risk groups. This has both positives and negatives. The main advantage is that the different organizations, in terms of their competence and expertise, can contribute more to the achievement of the set goals. A disadvantage is, however, the blurring of responsibility and possible inaction. 
As an obligatory element of the mentioned strategic documents at regional and local level there is the signing of a communication program, regulating the information flows, between both the institutions involved in the process of offering social services and the target audience outside this structure. There are also significant gaps in terms of imposed specific responsibilities of the participants and the lack of operationally prescribed communication techniques. The weakness is that it is not clear who decides what information, when, how and to whom to promote it. How will it be assessed whether it has reached its destination and whether it has achieved the desired effect. These significant shortcomings make it very difficult both to create an inter-institutional working environment and to send the right message to society and social service users in particular. It creates a feeling of a cumbersome institutional apparatus that does not exchange information with each other and often puts citizens in contradictory and absurd situations.

Apart from the mentioned bodies at regional and local level, Monitoring and Evaluation Units are established at each district administration, which continue their activity from the previous planning period. This speaks of ensuring continuity, which in itself is positive, but there are also many weaknesses, unresolved and insurmountable, which deepen the problems accumulated over time. The monitoring and evaluation units together with the district councils, incl. and extended staffs, have commitments for the implementation, monitoring and control of the district strategies for the development of social services. Often, however, ongoing monitoring reports are not developed, although their preparation is regulated. With regard to the evaluation of the results of the implemented social policy, it is not explicitly stated how, when and by whom it will be evaluated and respectively what measures will be taken when establishing negative or positive results from them. This fact is a prerequisite for the collective inertia of the institutions in this respect, which in turn violates the adequacy of their control functions and leads to a reactive approach to social policy.

\section{EFFECTS OF THE CURRENT INSTITUTIONAL SYSTEM FOR SOCIAL SERVICES}

At present in Bulgaria there is a very complex institutional system in the field of management of the processes of providing social services. Depending on the normative regulation of their powers, public administrations are responsible for different areas of social policy. The complex institutional organization leads to problems related to difficult communication, complicated bureaucracy, blurring of powers, low efficiency, effectiveness and expediency of the functioning of the public sector engaged in the preparation and implementation of public policies in the social sphere.

In organizational terms, the provision of social services and the performance of social activities with direct access to users in the Republic of Bulgaria is delegated to the municipalities. At the same time, due to limited resources and capacity, many of them, especially the smaller ones, fail to provide adequate support for some specific needs.

Despite the wide range of institutions involved in the implementation of social policy, the provided social services are developed in fragments. The levers for their provision are in the hands of different institutions, which makes it difficult to obtain combined services for persons at risk. Due to the territorial scope of the powers to provide social services and the way of their identification and financing, based on the so-called cost standards of the number of users, it is not possible to apply an integrated approach.

This is a reason for not covering the specific needs for social services and, accordingly, for the lack of equal access to support for the people in need, located in different municipalities. "Service providers have limited opportunities and incentives for cross-sectoral coordination and integrated service delivery (social and employment services, social assistance, education and health services) not only because of the administrative and budgetary procedures for the provision of social services, but also because local authorities do not have the tools to combine or improve coordination to better respond to identified risks through a holistic approach, which results is quality gaps in service delivery." (Световна банка, 2019)

The identification of and access to the needs for social services at the local level is based on a combination of two approaches: 1) support provided on request (demand-for-support, walk-in), and 2) categorical principle at the individual level. (Световна банка, 2019) In the first case, a request from the user of the service is required, i.e. his proactive behavior. This, in turn, requires him to be informed about the availability of such a service and the procedure for accessing it. The weaknesses of this approach are the lack of information, especially for marginalized groups, and they usually need social services the most. In addition, when the service is provided in cities, residents of smaller settlements have difficulty accessing it due to both ignorance and territorial distance. The solution is to provide mobile services to overcome both the information deficit and the physical access to services. However, the biggest weakness is the reactive nature of the services, as they are provided only when the problem arises and not preventively. (Световна банка, 2019) 
The categorical principle is related to the regulation of access depending on whether a person falls into predefined support categories. The main weakness here is the individual approach in assessing the need for services, in which several members may have the right of access in a given family and according to the current practices a separate procedure is conducted for each of them. This makes the service more expensive, makes it cumbersome and inefficient due to waste of resources.

The main weaknesses identified in the implementation of social policy based on the existing institutional organization are related to:

- Difficult access to social services that provide an effective response to the needs of people at risk;

- Lack of relationship between services and users due to reactive planning of needs;

- Normative identification and satisfaction of needs based on existing practices;

- Inability to provide coordinated integrated social services;

- Impaired coordination and communication in the implementation of social policies;

- Lack of a basic institutional centre to assign, organize and control the implementation of social policies, incl. strategies;

- Strong normative dependence and systematic underfunding of social services with a constant increase in the need for such;

- Strong centralization and concentration in public administrations of the process of providing social services to community users;

- Lack of flexibility in the provision of social services, caused by the lack of a system of tools for delivery of these services through various organizational forms - such as units, receptions, etc., serving a smaller circle of the population;

- Lack of sufficient quantity and quality of information provided in accessible language and in an appropriate way for existing and provided social services and the powers of the providers themselves;

- Limited outsourcing of social services and concentration of social activities in municipalities;

- Duplicate functions between institutions and overlapping of powers, respectively blurring of responsibilities.

Until the entry into force of the Social Services Act (Народно събрание Р България, 2020) in Bulgaria until the middle of 2020 , the normative base is characterized by a divisive approach to social policy, by deriving a separate normative document for each service. This leads to the development and implementation of uncoordinated and non-integrated policy, as a consequence of the lack of convergence in the regulatory framework and methodological guidelines. Social service policies are closely related to the legal framework, which details and specifies the provision of each service or the implementation of each activity. As a result, a numerous list of laws and regulations and strategic documents is established. "In general, the system of social policies abounds in administrative requirements and procedures that are not coordinated with each other, on the contrary - there is often duplication of requirements for users and activities for providers, as well as gaps in the provision of services." (Световна банка, 2019)

The social services planning system does not allow for innovation and response to needs. The provision of these services depends on two main administrative factors: 1) inclusion of the respective service in the regional strategy for development of social services and 2) condition of the infrastructure necessary for the provision of services by municipalities before the state approves the provision of a given service and secures its funding. Thus, the institutions involved in this process are at central, regional and municipal level, which in this format is ineffective in terms of organization and interaction.

The provision of social services is reduced to the normative ones, as the possibilities for cooperation are also normatively limited. Municipalities provide services within their territory and to their population. The very introduction of a new service - its planning, financing and provision is a closed process within the municipality. The financing of the process of providing social services on the basis of a single cost standard is inefficient and does not depend on the real needs, but on the capacity of the places for providing services. Due to the different provisions of the legal framework and the imposed powers, the coordination between the institutions engaged in social services and other sectors is insufficient. There is a unification of administrative efforts in the formation of public policies with a social focus, but at the stages of implementation and monitoring the participation is reduced to passive informing about the progress without specific commitments 
of the individual institutions. For this reason, the results of the implementation of strategies for the development of social services are formally reported, without a commitment to a sustainable impact from the implementation of this policy.

\section{INSTITUTIONAL ANALYSIS OF THE PLANNING PRACTICE OF SOCIAL SERVICES IN BULGARIA}

The system of social services is one of the most complex in each country and its analysis is facing many challenges. Depending on the chosen research method, different determinants of the system are clarified and partial conclusions are made about the way it works. They are often fragmented and valid only for a specific context. This is a major weakness of research in the field of social systems in general and is an indicator of the insufficient link between theory and practice.

\subsection{Transaction Costs for Social Services}

In the present study, the institutional analysis of the planning of social services is based on the approach of methodological individualism, which seeks explanations in social knowledge based on individuals and their properties, motives, goals and beliefs. (Проданов, 2003) The object of analysis are the desires (plans) of the economic agents, which at a certain moment are coordinated and thus transactions are carried out. They have certain incentives that motivate them to act in one way or another. At the same time, no one has all the necessary resources (material, human, financial and access to information) and therefore cannot function without the others. When the resources sought are key, valuable, or rare (Barney, 1991) and there is an ongoing exchange, participants become increasingly dependent on each other and therefore increasingly need coordination (Cho S, Gillespie DF, 2006).

The aim of the social services system is to provide quality services, but at a price acceptable to society. In other words, it is necessary to take into account transaction costs, as they make a system more expensive, increase its friction - in the sense of K. Arrow (Arrow, 1969) and slow it down.

Transaction costs for social services can be divided into two categories: ex ante and ex post costs, i.e. such before and after the provision of the service (Уильямсон, 1996). The preliminary ones are related to searching for information, negotiating and quantifying the transformation costs (for the development of the services, not for their transfer). Ex-post transaction costs are those that are incurred during and after the provision of the services. These are the costs of monitoring, protecting property rights and avoiding opportunistic behavior. The latter are related to the efforts made by the system for prevention of corruption and correction of defects and deviations. They are the most elusive, but also invariably present in modern business relationships.

The question of measuring transaction costs for social services has not yet been resolved either in theory or in practice. There are two approaches to this - the cardinalist or ordinalist approach. The first refers to the quantitative measurement (value) of all types of transaction costs. However, due to the hidden nature of some of them, for example to assessment the losses from corruption and leakages from the system, it is applied only approximately. The ordinalist approach, in turn, assumes the ranking of the various options, which allows to avoid measuring the volume of transaction costs (Господинов, 2014), but again does not give a complete picture of the system. (Terziev, 2019)

Social services in Bulgaria are financed with public funds from the central or local budgets. Most of the services are activities delegated by the State and for them the local budgets receive funds according to approved spending standards. Another part of the services is co-financed from local budgets, as user fees cannot cover the costs of providing them. The organization of providing social services in territorial aspect is in the competence of the local executive (mayor of the municipality) and legislative power (municipal council) (Народно събрание Р България, 2020). In this sense, central and local government are representatives of demand, as social services are part of the powers of public authorities. At the same time, however, municipalities are given the opportunity through their own structures (usually in the form of centers) or municipal enterprises to provide social services themselves or to outsource their provision to private providers.

In this case, we must distinguish between consumers and buyers. Consumers use social services but do not pay for them or do not pay for them in full. Buyers (the state through central institutions and municipalities) pay suppliers. Thus, the municipalities perform several functions simultaneously:

- Implement at the local level the set national goals of social policy, i.e. they are intermediaries between the central government and the users of social services; 
- Organize the delivery of social services, i.e. they are an intermediary between service providers and users;

- Independently organize the delivery of social services.

When municipalities participate both on the demand side (they pay for the services of the suppliers) and on the supply side (they themselves provide services to the consumers), the negotiation process can be distorted. The decision on whether the municipality should provide a social service or assign it to a private provider is limited by the capacity of the municipality (necessary resources) and the applicable legal framework governing the procedure. This increases transaction costs to avoid opportunistic behavior, which in some cases may be at the expense of service quality. The outcome is a change in the regulatory framework and the introduction of quality standards on the one hand and adequate control over their implementation on the other hand to regulate control over transaction costs.

\subsection{Planning of Social Services}

The commitments of the local government on the planning of social services, which are fully or partially financed from the state budget, are related to: 1) the analysis of the need for services and 2) proposals for services that will be provided at the local level. Based on this, the Social Assistance Agency analyzes the needs at the national level for social services financed from the budget and develops a proposal for a National Map of Social Services. (Народно събрание Р България, 2020).



Figure 1. Social services planning process

Thus, the analysis and planning of social services go through all hierarchical levels of the system and the process must end with a common document for the necessary services.

In practice, however, breakthroughs can occur at any stage of the process, and institutional analysis is a very suitable tool for identifying them. In order to clarify the potential deviations, it is necessary to trace the motives of the participants, which would be in conflict with the established norms, values and rules. A typical example of this is the process of needs analysis itself. According to the legislation and established practices, it is carried out with the participation of many stakeholders. This almost always prolongs and complicates the assessment for various reasons, incl. conflicts between participants. The Social Services Act in Bulgaria itself has undergone a long and painful discussion precisely because of the difficult process of coordinating the opinions of interested groups and organizations.

If we use a causal loop diagram to represent this example, it looks like this:
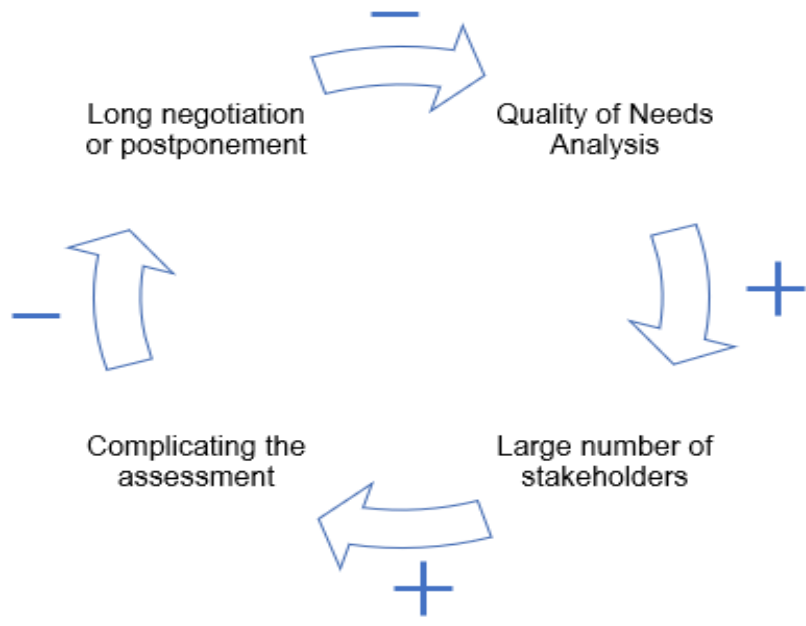

Figure 2. Needs Analysis - Causal loop diagram.

The diagram includes two positive and two negative factors. If we want to improve the quality of needs analysis (+ sign), we need to involve a large number of stakeholders (+). However, this can have a negative effect because it will complicate the assessment (-) and lead to lengthy negotiations or even postponement 
of the result (-). When the number of positive and negative factors is equal, the system is balanced and this is a problem because the goals cannot be achieved (development of a qualitative needs analysis). In order to break the cycle, it is necessary to plan additional interventions with a positive sign, for example in relation to conflicts between participants, assessing in advance their interests and motives.

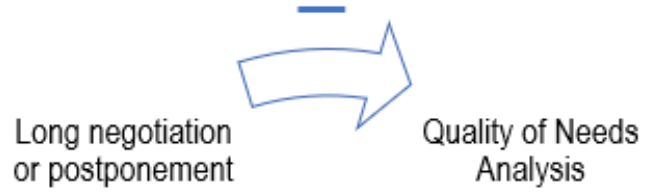

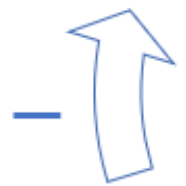

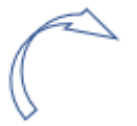

Complicating the assessment

Preliminary assessment of interests and motives
Analysis

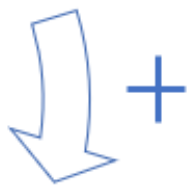

Large number of stakeholders

Figure 3. Needs Analysis - Causal loop diagram with intervention

This example of deviation only illustrates possible breakthroughs in the process of planning and implementing services. These can occur for many reasons, but due to the limited scope of the present study, it is not possible to study and demonstrate them exhaustively.

Other major problems are the staffing of the services sector, insufficient digitalization, etc. As the system is still being reformed towards decentralization, serious shortages of certain skills persist in some regions. Trainings are held to improve the qualifications of new employees (positive intervention), but the process requires time to accumulate expert capacity.

\section{CONCLUSION}

The social policies of most countries around the world are in a complex period, influenced by demographic change, economic development, which requires serious investment and reforms in service systems. The ensuing pandemic exacerbated the problems and posed new challenges to all governments. In this context, the efficiency of the systems becomes even more important as resources decrease and needs increase.

The social system is dynamic, but at the same time it is characterized by relative stability of preferences. This means that its participants - users of social services, providers, intermediaries (local government), are reluctant to change their preferences, and their behaviour is predictable. This important feature makes institutional analysis particularly suitable for in-depth studies, as it makes it possible to build relatively sustainable patterns of participant behaviour and to design corrective measures when they are found to be necessary.

In this publication, informal relations, such as customs, culture and attitudes of local communities, as well as personal relations between the participants in the process, remain outside the analysis. They can be both a favourable factor and a barrier to quality social services and hinder the whole process.

The connection of social services with digitalization, which can lead to a serious breakthrough in all public systems, has not been considered either. The next level of information technology is expected to create new, more efficient and effective information management opportunities, and hence to reduce transaction costs and to change management and behaviour patterns throughout the system. 


\section{REFERENCE LIST}

Barney, J. B. (1991). Firm Resources and Sustained Competitive Advantage,. Journal of Management, 17(1): 99-120.

Berim Ramosaj, Gentrit Berisha. (June 2014 r.). Systems Theory and Systems Approach to Leadership . ILIRIA International Review.

Bunger, A. C. (1 Oct 2010 r.). Defining Service Coordination: A Social Work Perspective. J Soc Serv Res. 36(5), стр. 385-401. doi:doi: 10.1080/01488376.2010.510931

Cho S, Gillespie DF. (2006). A conceptual model exploring the dynamics of government-nonprofit service delivery. Nonprofit and Voluntary Sector Quarterly. 2006;35(3):493-509. doi: 10.1177/0899764006289327.

Davidson, S. M. (1976). Planning and Coordination of Social Services in Multiorganizational Contexts. Social Service Review, Vol. 50, No. 1, стр. 117-137.

Jurevicius, O. (21 October 2013 r.). VRIO Framework. Извлечено от https://strategicmanagementinsight.com/tools/vrio.html

Lindblom. (1965). The intelligence of democracy. New York: The Free Press, стр. 335.

Rumelt, R. P. (1991). How Much Does Industry Matter. Strategic Management Journal, 12: 167-185.

Selden, S., Sowa, J., Sandfort, J. (2002). The impact of nonprofit collaboration in early child care and education on management and program outcomes. Public Administration Review, 66(3), стр. 412-425.

Starnes, B. J. (2001). Achieving Competitive Advantage Through the Application of Open Systems Theory and the Development of Strategic Alliances: A Guide for Managers of Nonprofit Organizations, . Journal of Nonprofit \& Public Sector Marketing, 8:2, 15.

Народно събрание Р България. (2020). Закон за социалните услуги. бн. ДВ. бр.24 от 22 Март 2019г., изм. ДВ. бр.101 от 27 Декември 2019г., изм. ДВ. бр.65 от 21 Юли 2020г., изм. и доп. ДВ. бр.71 от 11 Август 2020г.

Народно събрание Р България. (2020). Закон за социалните услуги. бн. ДВ. бр.24 от 22 Март 2019г., изм. ДВ. бр.101 от 27 Декември 2019г., изм. ДВ. бр.65 от 21 Юли 2020г., изм. и доп. ДВ. бр.71 от 11 Август 2020г.

Световна банка. (2019). Хармонизиране на услугите за включващ растеж. Подобряване на достъпа до основни услуги за уязвими групи в България. Технически доклад 2019. Световна банка.

Винокуров, С и др. (2013). Институциональная экономика. Издательство Санкт-петербургского государственного экономического университета. Санкт-Петербург.

https://unecon.ru/sites/default/files/instit_ekonomika_uchebnoe_posobie.pdf

Кънев, М. (2005). Неокласическият институционализъм в икономическата мисъл - една българска традиция. Диалог, (1). https://www2.uni-svishtov.bg/dialog_old/2005/1MKanev-BogDant.pdf

Лазаров, Р. (2013). Икономическата неопределеност и ролята на институционалния фрактор при нейния анализ. Икономика 21, (2). https://www2.uni-svishtov.bg/economics21/title.asp?title=297

Норт, Д. (1997). Вклад неоинституционализма в понимание проблем переходной экономики. http://www.finansy.ru/publ/north.htm

Норт, Д. (2000). Институции, институционална промяна и икономическо развитие. ЛиК София.

Олейник, А. (2002). Институциональная экономика. ИНФРА-М. Москва. https://booksforeconomi.ucoz.ru/instit/oleynik-institucionalnaya_ekonomika.pdf 